\title{
LITURGIA I TEOLOGIA CHRZTU SW. AUGUSTYNA W MEDIOLANIE
}

Mediolańska liturgia chrztu jest poświadczona przez św. Ambrożego głównio $w$ "De sacramentis"1 1 "De mysterils" a ponadto w:"De Helia et Ieiunio"3, "Expositio Psalmi 118"4, "De Noe et arca" "De Isaac vel anima"6" "De Spiritu Sancto"7 "Bxplanatio symboli ad Initiandos" 1 w "Bxpositio Evangeli1 secundum Lucam" ${ }^{9}$.

Kandydaci do chrztu wyrazali na poczatku Wielkiego Postu pragnienie przyjęcia sakramentu inicjacji chrześcijańskiej nocy z Wielkiej Soboty na Niedziele Wielkanocna. Czas Wielkiego Postu był okresem najblizszego przygotowania do przyjecia sakramentu chrztu, a polegał on głównie na słuchaniu codziennych pouczeá wygłaszanych w formie katechezy ${ }^{10}$. W $387 \mathrm{r}$. Popielec przypadal 10 marca, a Wielka Sobota 24 kwietnia. W nocy $z 24$ na 25 kwietnia wraz ze sw. Augustynem przyjeli chrzest Adeodat 1 Alipiusz. Późniejszy Biskup Hippony o snym chrzcie napisaz ni ewiele:

1 De sacrament1s, SCh 25 b1s, 60-155, tłum. L. Gładyszewski, POK 26, 54-93.

2 De mysteriis, SCh 25 b1s, 156-196, tłum. L. Gładyszewski, POK 26, 31-93.

3 De Helia et leiunio, CSEL 32/2, 411-465.

4 Expositio in psalmum 118, PL 15, 1197-1526.

5 De Noe et arca, PL 14, 361-416.

6 De Isaac vel anima, PL 14, 527-560, tłum. P. Libera, PSP 25/2, 123-172.

7 De Spiritu Sancto, PL 16, 731-850.

8 Explanatio Symboli ad Initiandos, SCh 25 bis, 46-59, tłum. L. Gładyszewski, POK 26, 21-30.

9 Expositio Evangeli1 secundum Lucam, CCL 14, 1-4C0, wybór tłum. Sz. Pieszczoch, POK 26, 94-102, całość tłum. W. Szołdrsk1, PSP 26.

10 Por. De Helia et leiunio 21, 79, CSEL 32/2, 460-461. 


\begin{abstract}
"Przyjęliśmy chrzest 1 rozwiał się niepokój o minione źycie. Nie mogłem sie w owych dniach nasycić cudowna słodycza rozmyślania o głębi Twego planu zbawienta ludzkości. Ileż razy płakałem słuchając hymnów Twoich 1 kantyków, wstrząśnięty błogim śpiewen Twego Kościoła. Głosy te wlewały się do moich uszu, a gdy Twoja prawda ściekała kroplami do serca, parowało z niego gorace uczucie pobożnego oddania. L oczu płynęły łzy 1 dobrze mi było z nimi"11.
\end{abstract}

Liturgia chrztu sprawowana przez św. Ambrożego składała się z trzech głównych części: z obrzędów przedchrzcielnych, chrzcielnych $i$ pochrzcielnych ${ }^{12}$.

\title{
I. OBRZEDY PIZEDCilliZCIELNE
}

Obrzędy przedchrzcielne obejmowały mysteria apertionis, namaszczenie przedchrzeciel ne $i$ wyrzeczenie sie szatana.

\section{1/ Mysteria apertionis - obrzędy otwarcia}

Obrzędy otwarcia składały sie z części katechetycznej

1 egzorcyzmów. Do części katechetycznej należały: traditio

Symboli, apertio narium 1 apertio aurium. Szereg obrzędow stanowiły tzw. "scrutamina". Ambroży łączy je z egzorcyzman1 oczyszczającymi ciało i dusze od wszelkiej nieczystośc1 ${ }^{13}$. Po ceremonil odżegnywania złego ducha biskup objaśniał poszczególne prawdy wiary 1 przekazywał Symbol wiary/traditio Symboli/14. zakazując zapisywania i czynienia notatek ze względu na konie-

11 Confessiones IX $6,14, \operatorname{CCL} 27,141$, tłum. Z. Kubiak/Swiety Augustyn, Wyznania, Warszawa 1987/200.

12 Dobre opracowanie sakramentów inicjacji chrześcijańskiej w liturgil mediolańskiej por.Hadrianus Caprioli, Battesimo e confermazione. Studio storico sulla liturgia e catechesi di S. Ambrogio, Varese 1977.

13 Por. Explanatio Symboli ad initiandos 1, SCh 25 bis, 46 , POK 26, 25 .

14 Tamże, por także 9, SCh 25 bis, 56-58, POK 26, 29-30: Epistula 20, 4, PL 16, 1037 . 
czność zachowania tajemnicy przed poganami, którzy mogliby znieważyé ten cenny depozyt wiary. Katechumeni opanowywali pamięciowo prawdy wiary i uczyli sie Symbolu wiary, a następnie w IV niedziele Wielkiego Postu, wygłaszali je głośno przed wspólnotą; był to egzamin zwany "oddaniem Symbolu" /redditio Symbol1/15.

"Apertio narium" i "apertio aurium" katechumena dokonywano wielka Sobotę. Biskup dotykał nozdrzy i uszu kandydata do chrztu mówiąc: "Effetha, to jest otwórz się"16. Wydaje się, że Ambroży przekazuje to zdanie jako formułę liturgiczną, a powołując się na Mk 7, 34 uzasadnia, dlaczego dotykał nozdrzy a nie ust. Jego zdaniem bowiem można było dotknąé warg mężczyzny, ale nie wypadało dotykać kobiety ${ }^{17}$. Biskup Mediolanu nie czynił znaku krzyża na czole, chociaż przypomina, że "Już katechumen wierzy w Krzyź Pana Jezusa, żegna się nim, lecz dopóki nie zostanie ochrzczony w imie ojca i Syna $i$ Ducha Swiętego/Mt 28, 19/, nie może otrzymać odpuszczenia grzechów ani zaczerpnąć daru duchowej łaski"18. "Apertio" jest obrzędem, któryu Bóg przez pouczenie biskupa wzywa człowieka do wiary, "aby każy, kto ma podejść do łaski, wiedział, o co zostanie zapytany i pamiętał, co ma odpowiedzieć"19. Biskup nauczał:

\footnotetext{
"Kapłan dotknął twoich uszu po to, by otworzyły sie na słowa jego pouczenia. Ale powiesz: 'Czemu dotykał też nosa?'/... Dlaczego waśnie nosa? Aby człowiek otrzymał miły zapach wi aczystego szczęścia i mógł powiedzieć: 'Jesteśmy dobrą wonnościa Chrystusa dla Boga'/2 Kor 2, 15/ jak mówi Apostoł - a także żeby zapalić mocny ogień wiary 1 pobożności"20.
}

15 Por. E. Bulanda, Wajenniczenie chrześcijaískie, AK 57/1965/ t. 68, 129-137, zwłaszcza s. 134; A. Bober, AP 182 .

16 Por. De mysteriis 1, 3, SCh 25 bis, 156; De sacramentis I 1, 2, SCh 25 bis, 60, POK 26, 36 i 54 .

17 Por. De mysteriis 1, 4, SCh 25 bis, 156; De sacranentis I 1, $2-3$, SCh 25 bis, 61-62.

18 De mysteriis $4,20, \mathrm{SCh} 25$ bis, 166, POK 26, 40.

19 De mysteriis $1,3, \mathrm{SCh} 25$ bis, 156, POK 26, 36.

$20 \nu_{e}$ sacramentis I 1, 2-3, SCh 25 bis, 60 ; P(K $26,54$. 


\section{2/ Namaszczenie przedchrzcielne}

Po obrzędzie "apertionis" katechumeni wchodzili do chrzcielnicy i tam w czasie namaszczenia wyrzekali sie szatana 1 jego uczynków, swawoli $i$ rozkoszy ${ }^{21}$. Namaszczenia dokonywał diakon lub kapłan. Przyjmujący chrzest zdjął prawdopodobnie wcześniej szaty. Obraz zapaśnika, o którym wspomina Ambroży, nasuwa myśl, że namaszczente praktykowano na całym ciele ${ }^{22}$. Namaszczenie ukazywało przyjmującemu chrzest dramatyczne znaczenie walki, jaka decyduje się podjąć z szatanem z chwila wpisania go na liste kandydat6w do chrztu ${ }^{23}$. Kandydat do chrztu wchodził jak atleta na arenę $i$ został namaszczony do walki. Istnieje ciagłość między namaszczeniem "obrzędowyr" na ciele przyjmującego chrzest, a namaszczeniem "duchowym", które katechumen przyjmował codziennie w czasie Wielkiego Postu przez codzienne pouczenia o słowie Pana i Jego przykazaniach oraz przez ćwiczenia wielisopostne, ażeby stać się atleta Chrystusa 24 .

Obrzęd namaszczenia przed chrztem był - jak się zdaje wtórną 1 uzupełniająca czynnościa w stosunku do obrzędu "apertionis", jeśli się zwróci uwage na to, iż "apertio" dokonywał biskup, namaszczenia zaś lewita /= diakon/ lub kapłan. Ambroży mówi o namaszczeniu duchowym chrześcijanina przed chrztel, aby w ten sposób wyjaśnić wezwanie do wiary w czasie chrztu. Kolejność obrzędón ma więc dla Biskupa wyraźne znaczenie katechetycz$n e^{25}$.

\section{3/ Wyrzeczenie się szatana}

Ambroży przekazuje dwie formuły wyrzeczenia się: bezpośrednia w "De sacramentis" 1 pośrednia, w "Do mysteris". Biskup przypominal neofitom:

21 Por. De mysteriis $/ 2,5, \mathrm{SCh} 25 \mathrm{bis} /, 158$; De sacramentis $\mathrm{I} 2,4, \mathrm{SCh} 25$ bis, 62 .

22 Por. De sacramentis I $2,4, \mathrm{SCh} 25$ bis, 62.

23 Por. De llelia et ieiunio 21, 79, CSEL 32/2, 460-461.

24 Por. Lixpositio in Psalmum 118, 20, 9, PL 15, 1486.

25 H. Caprioli, Battesino e confermazione, dz.cyt., 38 . 
"Co odpowiedziałeś, gdy cie zapytano: 'Czy odrzekasz sie diabłu i jego uczynków'? 'Odrzekam'.

'Czy odrzekasz sié świata i jego przyjemności?'

- co odpowiedziałeś? 'Odrzekaun'"26.

W "De mysteriis" zaś czytany:

"Powtórz, o co cie zajytano, przypomnij sobie, co odpowiedziałeś! Hyrzelłeś sie diabła i jego uczynków, świata $i$ jego swawoli i rozkoszy" 27 .

Katechumen, kierując się ku wschodowi, wyrzekał się diabła 28 wobec lewity, kapłana ${ }^{29}$ biskupa ${ }^{30}$. Wyrzeczenie sie szatana stanowiło obietnice spłacenia długu, jaki dłużnik jest winien swemu wierzycielowi ${ }^{31}$. Obraz dłuźnika i wierzyciela podkreśla konieczność dotrzymania wierności obietnicora. Lapewnienie katechumena było szczególnie ważne ze względu na miejsce jego złożenia i osoby, któryli obiecywał. Ducilowni przyjmowali od kandydata obietnice nie jako osoby prywatne, ale jako słudzy Chrystusa i Kościoła. Anbroży podkreślał w przysięuze przede wszystkim kontekst kościelny. Obietnica składana wobec Kościoła jest ważna nie tyliko na ziemi, ale także wobec Boga. Słudzy Kościoła zajmuja miejsce aniołów, a przede wszystkim Anioła zapowiedzianego przez proroków, którym jest Jezus Chrystus ${ }^{32}$. Przyrzeczenia zatem złożone wobec ministrów ḱościoła/diakona, kapłana, biskupa/ sa ostatecznie dane samenu Chrystusori. Obietnica ta stanowiła wyrzeczenie się przez katechumena wszelkiego zwi azku z szatanem i ze społecznościaz pogańskiz.

\section{OBHZEDY CIRZTU}

Sw. Ambroży "De sacranentis" informuje, że "zazwyczaj forma chrztu jest taka, iz najpierw zostaje poświęcona sadzawka

26 De sacramentis I 2, 5, SCh 25 bis, 62; POK 26, 55.

27 De nysteriis 2, 5, SCh 25 bis, 158; POK 26, 36.

28 Por. De mysteriis $2,7, \mathrm{SCh} 25$ bis, 158; POK 26, 37.

29 Por. De sacramentis. I 2, 4, SCh 25 bis, 62, POK 26, 54 .

30 Por. De mysteriis 2, $6 \mathrm{i} 3,8, \mathrm{SCh} 25$ bis, 158, POK 26, 36-37.

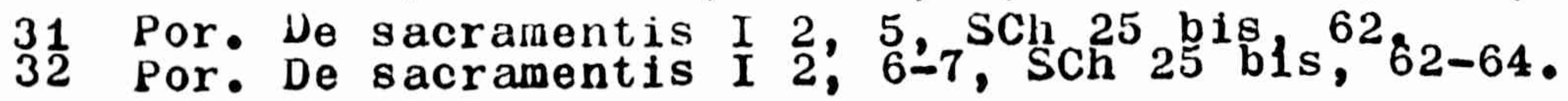


chrzcielna, a dopiero potein wchodzi doú ten, kto ma przyjać chrzest" 33 . Liturgia chrztu składała się zatem według niego z dwóch zasadniczych części: z poświęcenia źródła oraz obmycia i zanurzenia neofity.

1/ Poświęcenie źródła chrzcielnego

W poświęceniu Ĺródła chrzcielnego wyróżniał Ambroży znów dwie części: egzorcyzm i wezwanie, o czym we wtorek po wielkanocy pouczał nowo ocinrzczonych:

"/.../ kapłan, dokonuje nad wodą egzorcyzuów, następnie zanosi błagania $i$ modły o uświęcenie źródła chrzcielnego i o obecność wieczystej Trój cy"34.

Biskup Mediolanu ani w "De sacramentis" ani w "De mysterils" nie przekazał formuły egzorcyzmu wypowiadanego nad woda. Wprowadzajac natomiast biblijna typologię podejmuje temat wyższości sakramentów chrześcijańskich nad obrzędami żydowskini ${ }^{35}$ i pogańskimi ${ }^{36}$. Mówiąc o widzialnych znakach sakramentu chrztu/woda, biskup, lewita/, podkreśla jego niewidzialną działal ność jako przedtuzenie dzialania samego Boga Zbawiciela od stworzenia aż do chrztu Jezusa w Jordanie, który wypełnia wszystkie figury chrztu w Starym Testanencie. Wykazuje również wyższą niewidzial ną działalność chrztu w stosunku do wody i ministrów: w chrzcie urzeczywistnia się pełnia łaski i uświęcenia ${ }^{37}$.

Po egzorcyzmie następowała modlitwa wzywająca, w której kapłan zanosił prośby o uświęcenie źródła chrzcielnego 1 o obecność osób Bożych ${ }^{38}$. Biskup Mediolanu całej Trójcy Świętej przypisywał działanie uświęcenta w chrzcie, chociaź poucza neofitów o różnyn porządku tej obecności. Iy chrzcie Jezusa w Jordanie najpierw Jezus wszedł do wody, pózniej zstapił na Niego Duch Święty w postaci gołębicy. obecnie natowiast w chrzcie najpierw zostaje

33 De sacramentis I $5,18, \mathrm{SCh} 25 \mathrm{bis}, 70$, POK $26,58$.

34 Tainże.

35 Por. De sacramentis I 6, 23, SCh 25 bis, 72 .

36 Por. De sacramentis II $1,2, \operatorname{SCh} 25$ bis, 74 .

37 Por. De sacramentis I 3,10 , SCh 25 bis, 64-66.

38 Por. De sacramentis I 5, 15-19, SCh 25 bis, 68-70. 
przez Ducha Świętego uświęcone źródło, a poten zstępuje do niego neofita. Ambrozy przytacza nakaz chrztu /Mt 28, 19/, a skuteczność słowa kapłana wi aże ze skutecznością słów Pana Jezusa. Tę ostatnią objaśnia, nawiązując do wydarzeń zarówno Starego /Wj $15,23-26 /$, jak $i$ Nowego Testamentu, a przede wsystkim do chrztu Jezusa w Jordanie ${ }^{39}$.

W czasie odmawiania modlitwy wzywającej kapłan, jak świadczy o tym św. Augustyn, czynił znak krzyża Chrystusowego, którym sa naznaczone dla nas wszelkie dobra, jakie otrzynujeny sprawując Jego sakranenty. Modlitwa błogosławiąca wodę chrzcielną nawiązywała do tajemnicy krzyża ${ }^{40}$. Pewne typologie Starego Testamentu tiumaczy Ambroży jako figury poprzedzające tajelinicę krzyża działająca 1 obecnaz w źródle cirrzcielnya41. Szcze rólne znaczenie obecności tajemnicy krzycia ma według niego woda, która wytrysnęza z boizu ukrzyzowanego Chrystusa:

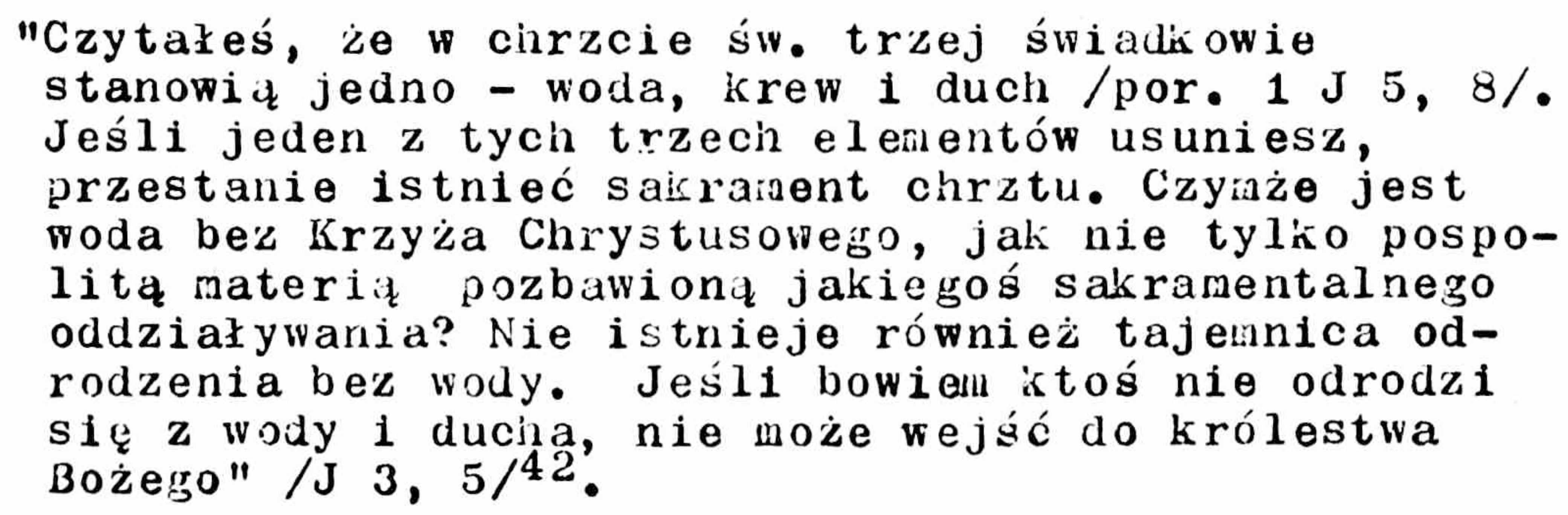

Znaczenie 1 pochwałę wody przedstawił Ambroży w "Wykładzie Ewangeli1 według św. Lukasza", zaliczając ją do trzech świadków naszego odrodzenia: "trzech bowien jest świadków: 'woda, krew

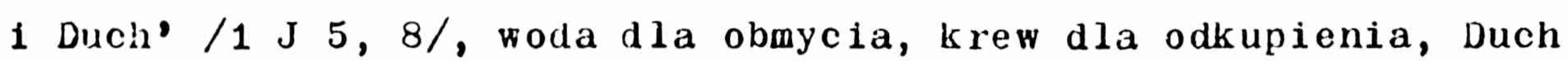

39 Por. De mysteriis $3,14, \mathrm{SCh} 25$ bis, 162; De sacramentis III $2,14-15, \operatorname{SCh} 25$ bis, 100 .

40 Por. In Joannis tivangelium tractatus $118,5, \mathrm{CCL} 36,657$, tłum. W. Szołdrski, PSP 15/2, 340; Sermo 352, PL 39, 1551.

41 De mysteriis 3,10-11, SCh 25 bis, 160; De sacramentis II 4, 11-13, SCh 25 bis, 78-80, POK 26, 37-38, 61-62.

42 De mysteriis 40, 20, SCh 25 bis, 166, POK 26, 39-40. 
dla wskrzeszenia" /aqua ad lavacrum, sanguis ad pretium, spiritus ad resurrectionem/ 43 .

Trylogia Janowa: woda, krew i Duch skłoniła Ambrożego do szerszego spojrzenia na cały proces chrztu od katechumenatu do eucharystii $i$ na stwierdzenie stałego $i$ stopniowego świadectwa w skuteczność tajemnicy Krzyza: "Już katechumen wierzy w Krzyz Pana Jezusa, żegna sie nim", ale dopiero w chrzcie ta tajemnica objawia się w całej swej skuteczności, bo "dopóki nie zostanie ochrzczony ${ }^{6} w$ imię Ojca i Syna 1 Ducha Swietego /Mt 28, 19/, nie może otrzyuać odpuszczenia grzechów ani zaczerpnąć daru duchowej łaski"44.

Modlitwa biskupa nad źródłem chrzcielnym 1 znak krzyża nakreślony nad wodiz, wskazuje katechumenom na szczególny zwiazek błogosławieństwa źródła chrzcielnego z tajemnica krzyża. Błogosławieństwo zródła ma dla Ambrożego wymiar chrystologiczny. Zywa zaś wiara w obecnosć Pana Jezusa, w Jego słowa 1 tajemnice krzyża przyjmuje w katechezie Biskupa Mediolanu także wyraźny wymiar kościelny. Skuteczności słów Chrystusa 1 tajemnicy krzyża przepowiadanej w błogosławieństwie wody, nie można oddzialić od tajeanicy jedności z Kościołem, szczególnie z kapłaństwem hierarchicznym. Ukazuje on powiązania między obecnością Chrystusa i Kościoła, pomiędzy skutecznościa słowa Chrystusa 1 widzialnym posługiwaniem biskupa i jego współpracownikóm ${ }^{45}$. Obrzęd poświęcenia źródła składał się zatem z długiej modlitwy, która kapłan albo biskup odınawiał nad woda, przypominając jej pochodzenie od Boga $i$ powiązanie $z$ wielkimi wydarzeniami, jakich Bóg dokonał w historii zbawienia oraz przywoływał obecność osób Bożych dla uświęcenia tego, który do tej wody miał wstąpic 1 przyjąć chrzest. Cała ta długa modiltwa podkreśla wzczególny sposób skuteczność działania słowa Chrystusa i tajemnicy Jego śmiorci na krzyźu za pośrednictwem kapłana.

\section{2/ Obmycie i zanurzenie neofity}

Spróbujmy teraz zrekonstruować ambrozjaíski ryt chrztu w swietle ję̧o pism. Przyjinujacy chrzest stawał nago, by przez

43 Expositio Lvangeli1 secundum Lucam X 48, CCL 14, 359, PSP 16,423 .

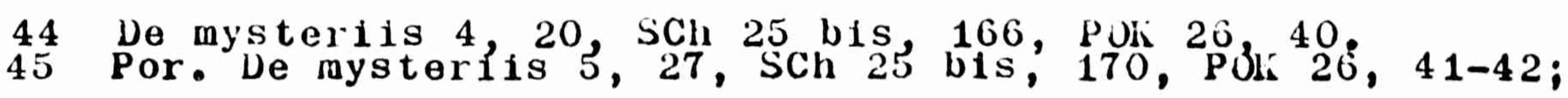


chrzest zostać odrodzonym do zycia chrystusie, podobnie jak nagi rozpocząz życie doczesne ${ }^{46}$. Po wejściu do basenu zanurzał się nim trzykrotnie, prawdopodobnie częściowo, gdyź nie mógz tego uczynić całkowicie, bo basen był głęboki na $80 \mathrm{~cm}^{47}$. Ambrozy zwracając się swej katechezle do neofitów uźwal terminu "mersisti", a nie "mersus es", co pozwala przypuszczać, iz ochrzczony sam zanurzał głowę 1 w ten sposób czynnie współdziałał akcie własnego chrztu ${ }^{48}$. Inni uwazają, ze katechumen wchodził do basenu z kilkoma szafarzami, diakonami lub kapłanam1, którzy mu towarzyszyli w akcie chrztu św. mylewając na jego głowę wode chrzcielna, za kazdym razem w czasie trzykrotnego wyznania wiary". W "De sacramentis" podaje Biskup Mediolanu liturgiczny tekst wyznania wiary, w którym jest mowa o trzykrotnym pytaniu biskupa 1 trzykrotnej odpowiedzi neofity:

\footnotetext{
"Zapytano cie: 'Czy wierzysz Boga 0jca wszechmogacego?' Powledzlałeś: 'Wierzę' 1 zanurzyłeś 81ę, to znaczy pogrzebano cie. Ponownie zapytano: 'Czy wierzysz $w$ Pana naszego Jezusa Chrystu8a 1 Wego krzyz?' Powiedziałes: 'Wierzę' 1 zanurzyłes się. Zostałeś więc rómieziezóółpogrzebany $z$ Chrystusem. A kto razem z Chrystusem zostaje pogrzebany, razem z Nim zmartwychwstaje. Po raz trzeci zapytano: 'Czy wierzysz 1 w Ducha Swiętego?' Powiedziałeś: 'Wierzę' 1 zanurzyłeś 81 e po raz trzeci, aby trzykrotno wyznanie wiary usunęto wielokrotnie w zyciu dotychczasowym popełnione grzechy"50.
}

Ambrozy przypisuje wyznaniu wiary wielkie znaczenie. W "De sacramentis" wyjaśnia znaczenie trzykrotnego wyznania wia-

H. Caprioli, Battesimo e confermazione, dz.cyt., 47-48.

46 Por. Explanatio Psalmi 61, 32, CSEL 64, 396.

47 Por. B. Filarska, Poczłtki sztuki chrześcijańskiej, Lubl1n 1986, 263.

48 Por. De sacramentis II 7, 20, SCh 25 bis, 84-86; por.il.Capriol1, Battegimo e confermazione, dz.cyt., 49; J. iv. Hanssens, La concelébration du cathecumene dans l acte de son bapteme, "Gregorianum" $27 / 1944 / 417-443$.

49 Por. D. Illert, Die Taufe bel Ambrosius von Mailand, K1el $1962,131 \mathrm{n}$.

De sacramentis II 7,20 , SCh 25 bis, 84-86, JOK $26,64$. 
ry: neofita nie powinien powracać do dawnych grzechów. Piotr trzy razy zaparł się Chrystusa 1 trzy razy wyznaz swoja miłość do Chrystusa ${ }^{51}$. Wyznanie wiary stanowi teź wyrażenie wiary Kościoła, uznanie doskonałej równości ojca, Syna 1 Ducha Swiętego oraz tajemnicy krzyza ${ }^{52}$. Podkreślenie tajemnicy krzyza stanowi pewne podobieństwo z poprzednim błogosławieństwem źródła chrzcielnego. Istnieje bowiem podobieństwo treści trynitarnej i chrystologicznej oraz tozsamość posługiwania głoszącego te tajemnice, to jest biskupa, który zadawał pytania i poświęcał ${ }^{53}$. Kościół domaga się od katechumena wyznania wiary 1 tą droga prowadzi go aż do chrztu. W sercu aktu chrztu neofita wyznaje wiarę, co stanowi takze uczestnictwo kandydata w akcie chrztu.

\section{OBRZEDY POCHRZCIELNE}

IV czasach Ambrożego i Augustyna żywa była świadomość jedności procesu inicjacji chrześcijańskiej. Być ochrzczonym oznaczało uczestniczyć w eucharystii i przeżywać wspólnote kościelną. Do obrzędów pochrzcielnych należało: namaszczenie po chrzcie, umycie nóg i nałożenie szaty.

\section{1/ Namaszczenie po chrzcie}

Zaraz po zanurzeniu i po potrójnym wyznaniu wiary neoita zblizał sie do kapłana lub biskupa. W "De sacramentis" Biskup Mediolanu zaznacza: "A więc zanurzyłeś się/mersisti/ 1 podszedłeś /venisti/ do kapłana" /ad sacerdotem/54 • W "De mysterils" zaś czytany: "Potem podszedłeś do biskupa"/post haec utique adscendist1 ad sacerdoteil/" Czasownik "adscendisti" nasuwa myśl wyjścia

51 Por. De sacramentis II $7,21, \mathrm{SCh} 25$ bis, 86.

52 Por. De mysteriis $5,28, \operatorname{SCh} 25$ b1s, 170 .

53 Por. De mysteriis $3,8, \mathrm{SCh} 25$ bis, 158.

54 De sacrament is II $7,24, \operatorname{SCh} 25$ bis, 88, POK $26,65$.

55 De mysteriis 6, 29, SCh 25 bis, 172, POK 26, 42. 
neofity z basenu chrzcielnejo, przejście na druga strone, gdzie stał biskup, który miał go namaśció. Przede wszystkim jednak wyrażenie to miało znaczenie duchowe: wstępowanie neofity ku pełni inicjacj1 chrześcijańskiej. Biskup trzyma w ręku krzyżmo/Ambroży nazywa je "myron"/ wcześniej pobłogosławione $i$ namaszcza nim neofite. Namaszczenie, jak się zdaje, polegało na wylaniu nagromadzonego w zagłębieniu dłoni krzyżma na głowę neofity. Wydaje sie, że taki był zwyczaj zacinodni aż do v wi eku ${ }^{56}$.

W "De sacramentis" podaje Ambroży nawet forıułę liturgiczną obrzędu namaszczenia po chrzcie: "Bóg Ojciec wszechmogący, który cię odrodził $z$ wody i Ducha i darował ci grzechy, on również namaszcza cię na życie wieczne"57. Lwrot "na życie wieczne" rozpowszechniony w pierwotnych formułach liturgicznych, oznacza nie tylko zbawienie ostateczne, ale także - jak u sw. Jana - obecne, urzeczywistnione za pośrednictwem odrodzenia przez chrzest ${ }^{58}$. Biskup Mediolanu utożsamia więc temat życia wiecznego z tematem wiary, którą naleźy wyznawać i zachowywać nienaruszona w obliczu wszelkich pokus herezji ${ }^{59}$. Wyjaśnia również zaczenie namaszczenia po chrzcie św. jako obrzędu pełnego włączenia albo przywrócenia neopity Chrystusowi w Kościele. Po chrzcie neofita "adscendit" w kierunku biskupa po to, ażeby namaścił mu głowe, $i$ aby cała działalnośc jego znysłów duchowych była zakorzeniona w Chrystusie jako głowie Kościoła. Ambroży inspirowany przez myśl księgi "Pieśni nad pieśniami"/1, 2/ nawiązuje w namaszczeniu po chrzcie do symbolu imienia Chrystusa: "olej wylany jest twoim imieniem"60. Imie Chrystusa pozostawał o przed Wcieleniem zanknięte w duszach narodu żydowskiego, jak woń w naczyniu. Dzięki Wcieleniu $i$ imię Chrystusa objęło wszystkie stworzenia 1 doznaje czci $w$ całym świecie ${ }^{61}$.

56 Por. Tertullianus, De baptisino 7, CCL 1, 282; Cyprianus, Epistola 70, 2, CSEL 3,768; Traditio Hippolyt1 21, SCh 11, 88; Basilius, De Spiritu Sancto $27,66, \mathrm{PG} 32,187$.

57 De sacramentis II 7,24 , SCh 25 bis, 88 , POK $26,65$.

58 Por. H. Caprioli, Battesimo e confermazione, dz.cyt., 60.

59 Por. De sacramentis II $7,24, \operatorname{SCh} 25$ bis, 88 .

60 De mysteriis 6, 29, SCh 25 bis, 172, POK 26, 42.

61 Por. De Spiritu Sancto I 8, 94-96, PL 16, 756-757. 
Biskup Mediolanu dostrzega też tej symbolico Kościół, który jest oblubieniç wspomniana już w "Pieśni nad pieśniami", że z niêrządnicy, wydającej przez swe grzechy złą woń, została pociagnięta przez wón imienia Jezusa do tajemnicy Chrystusa. Wonia Imienta Jezusa Chrystusa jest wiara Kośc1oła62, która wypelnia dom Pana63. Neofici sa pociagnięc1 wonia imienia Chrystusa, która unosi sie z Jego zmartwychwstania. W "De mysteri1s" nawlązuje Ambroży do synboliki oblubienicy z "Pieśni nad pieśniami", "De sacramentis" zaś do eucharysti1, ku której kierowane jest namaszczenie po chrzcie.

2/ Umycie nóg

W "De sacramentis" św. Ambroźego czytany:

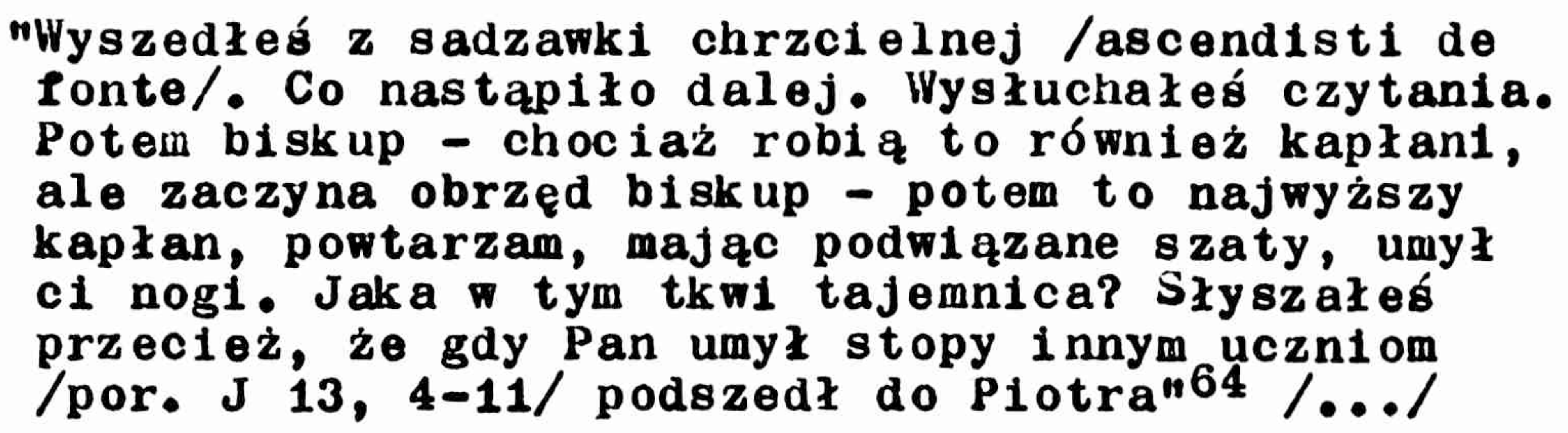

W przytoczonym Pragmencie powraca znane już w związku z namaszczeniem po chrzcie, wyrazenie "ascendisti". Wzmianka o umywaniu nóg uczniom przez Jezusa w czasie 0statniej Wieczerzy odnosi sie do czytania liturgicznego tego dnia. Perykopa Jana o obmyciu nóg stanowiła część "ordo lectionum", z czego Aubroźy czerpał natchnienie dla swolch katechez mistagogicznych"6. W "De mysterils" nie omawia wyraźnie obrzedu, ale kładzie jedynie nacisk na jego znaczenie 66 . W "De sacramentis" natomiast broni słuszności tego obrzędu wobec Kościoła rzymskiego, gdyz Rzym nie miał tego zwyczaju. Chociaz Biskup Mediolanu pragnaz dostosować sie we wszystkim

62 Por. Expositio in psalmum 118, 1, 5, PL 15, 1201-1202.

63 Por. Expositio Evangeli1 secundum Lucam VI 34, CCL 14, 186187, PSP 16, 223.

64 De sacramentis III $1,4, \operatorname{SCh} 25$ b1s, 92, РОK 26, 67.

65 Por. H. Caprioli, Battesimo e confermazione, dz.cyt., 67 ; F. Petit, Sur 10 s catecheses postbaptismales de S. Ambroise, RBen 68/1958/262-265.

66 Por. De mysteriis 6. 31-33, SCh 25 bis, 172-174. 
do liturgii rzymskioj, to jednak chciał teź zachować odrębności swojego Kościoła ${ }^{67}$, a skłoniły go do tego dwa motywy: sakramentalny 1 moralny ${ }^{68}$. Biskup posłuszny nakazowi Chrystusa 1 apostołów myje nog1, dokonując gestu oczyszczenia 1nnych 1 siebie samego. 0 myciu nóg mówi się tu w kontekście herezji, dzięki czemu obrzed ten nabiera znaczenta poszukiwania prawdziwej wiary 1 unikania herezj1: obmycie stóp przez biskupa oznacza przyjęcie wiary apostołóm, a odrzucenie herezji i własnych grzechów. W "De sacramentis" 1 w "De mysterils" Ambroży wyjaśnia ten obrzęd 1 bron1 go przed krytykującymi: umycie stóp jest nie tylko wyrazem gościnnośc1 1 pokory, ale stanowi także obrzęd oczyszczenta 1 uświęcenia, 1 dlatego jego obecność jest usprawiedliwiona po chrzcie sw. a przed eucharystią. Obrzęd ten uzupełnia oczyszczenie chrzcielne: chrzest oczyszcza z grzechów własnych, natomiast obmywanie stóp jest związane z "podstępem diabelskim" /subplantatio diaboli/, rzeczywistościa, która nie jest grzechem, ale prowadz1 do grzechu, zagrażając stopom stanowiącym podstawe chrześcijańskiego działania ${ }^{69}$. Obrzęd obmycia nóg prowadzi neoIite do eucharystii 1 jest czyms odrębnym od chrztu, spełniając role lekarstwa dla neofity, ażeby nie wpadz w grzech, przede wszystkim grzech herezji $i$ wokusy przeciw wierze.

Nadając temu obrzędowi interpretację sakramentalną, Ambroży nie odrźucał moralnej: skłania on chrześcijanina do naśladowania miłości Chrystusa, sługi pokory ${ }^{70}$. Neofita w chrzcie został oczyszczony z grzechów, namaszczenie zaś umocniło go przeciwko pokusom zagraźającym stałości, miłości 1 wierze. W umyciu stóp otrzymuje zach̨̧tę do miłości Chrystusa. Dusza przez wiare 1 miłość wznosi się do doskonałej jedności z Chrystusem w eucharystii.

67 Por. De sacramentis III 1, 5, SCh 25 bis, 94.

68 Por. B. Botting, Fusswaschung, RAC 8/1972/743-77; Ambrosius, Expositio Evangrelit secundum Lucain VI 65-68, CCL 14. 196-198, PSi 16, 233-235.

69 Por. De sacramentis III $1,7, \operatorname{SCh} 25$ bis, 94-96, De mysteriis $6,32, \mathrm{SCl}: 25 \mathrm{bis}, 172$.

70 Tasize; De nysteriis $6,33, \operatorname{SCh} 25$ bis, 174. 


\section{3/ Nałożenie szaty}

Po obmyciu stóp neofici otrzynywali białe szaty, co było radościza całego Kościoła, który gromadził sie woḱł nich ${ }^{71}$. IV "De mysteriis" św. Ambroży wyjaśnia to ważne wydarzenie czerpiąc natchnienle z tekstów biblijnych, zwłaszcza z "Pieśni nad pieśniani"72. Zasadniczym tematem tej ksieggi według niego jest wznoszenie sie duszy do doskonałego spotkania z Panem $\mathbf{F}$ Koście1e. Wyróznia przy tym dwa uniesienia duszy: ascetyczno-duchowe i obrzędowo-sakrainental ne, obydwa jednak są ze sobą głęboko powiązane w związku z namaszczeniem 1 przyodzianiem neoritów ${ }^{73}$. Obmycie stanowi punkt wyjścia wznoszenia sie na spotkanie z Chrystusem ${ }^{74}$, na które dusza winna przyodziać sie w pięknaz szatę, czyli dokonać nawrócenia moralno-ascetycznego ${ }^{.5}$. Nawiązując do tèsstów księg1 "Pieśni nad pieśniami" widział, w grupie neofitóiv odzianych w białe szaty, owczarnię, która idzie wzdłuź rzeki szukając pokarmu" 6 . Natomiast w "Komentarzu do Psalmu 118", który cizasowo wyprzedza "De mysteriis", przypomina typologie ksiegi "Pieśni nad pieśniami" i wyjaśnia, iż owczarnia, która opuszcza rzeke 1 pod przewodnictwem pasterzy udaje się na wysokie gćry, gdzie znajduje sie duźo pokarmu, jest wolna od niebezpieczeństw, zwierzęta zaś większe z macierzyńska troskliwościa dostarczaja pokarmu małym z tej owczarni. Owczarnia ta, opuszczajaca zbocza rzeki i szukająca pokarmu w górach, jest syuboler Kościoła, który razem z neofitami ziraca sie ku prawdziwej wierze i idzie na spotkanie z Chrystusem ${ }^{77}$. Cały więc obrzęd, nie tylko przyrdzianie neofitów w białe szaty, ale i scena przejścia neofitów od źródła chrzcielnego do uczty eucharystycznej, nabiera znaczenia wznoszenia sie ku Chrystusowi w Kościele, oznacza przyjecie nauki Chry-

71 Por. De sacrailentis III $1,5-6,5 C h 25$ bis, 94.

72 Por. De mysteriis $7,34-40$, SCh 25 bis, 174-175.

73 Taraze, 6, $2917,35-38$, SCh 25 bis, 172 1 174-176.

74 Tamże, 7, 34-3 .37 , Sch 25 bis, 174-176.

75 Tamze, 7, 38, SCh 25 bis, 176.

76 Tanż。

77 Por. Expositio in Psalmum 118, 16, 21-22, PL 15, 1431-1432; De mysteriis 7,38 , SCh 26 bis, 176 . 
stusa, przekazywanej w Jego Kościele oraz doskonalenie się dzięki Innys braciom w wierze.

$\nabla$ traistacie "De Isaac vel an1ma", będącym najprawdopodobniej rezultatem paschalnego nauczania ${ }^{78}$, przepojonyn równiez interpretacją "Pieśni nad pieśniami", Ambroży nawiązuje do obrazu trzody w odniesieniu do Kościoła, który przyjmuje do swego łona nowo ochrzcz onych 1 nos 1 ich $w$ sobie aź do doskonal ego spotkania z Panem na uczcle eucharystycznej. Kościóz jest dobrym pasterzem powołanym do pełnego jednoczenia z Chryștusem, troszczącym sie o braci w wierze, wspierającym zmęczonych, poszukującym zabłąkanych, karmiącym zgłodniałych 1 zblizającym wszystkich do Niego. Głęboka więź łączy grupę neofitów ze wspólnotą dążącą do zjednoczenia z Chrystusem ${ }^{79}$.

Złożoność obrzędów po chrzcie przedstawia Ambroży jako rozwój laski chrztu, przede wszystkim wiary 1 jedności kościelnej koniecznej do pełnego zjednoczenia z Chrystusem w elucharystii. obrzędy te ukazuja etapy źycia chrześcijańskiego ukierunkowane ku poszukiwaniu Chrystusa w Kościele. Wskazuja one również na potrzebę katechezy po chrzcie dla pełnego wtajemniczenia w kult duchowy/namaszczenie po chrzcie/, zapobieżenia przed rozłamem w Kościele /umycie nóg/, pogłębienia solidarności z braćmi i pomocy braclom w wierze na drodze ku Chrystusowi/nałożenie szat/.

Mediolańska liturgia inicjacji chrześcijańskiej składała się więc z różnych obrzęiów, a każdy z nich był bogaty w szczegółowe znaczenia. Dostrzega się w nich przede wszystkim jedność liturgiczną $i$ kościel ną sakramentów Inicjacj 1 chrześcijarískiej: chrztu 1 bierzmowania. Wskutek jednak nạływu mas do chrześcijaństira, coraz trudniej było o biskupa, który by przewodniczył inicjacj1 chrześcijańskiej. Powstał wówczas problem: czy przewodnictwo w liturgii inicjacji pozostawić w całości kapłanowi, zachowujizc w ten sposób jedność celebracji chrztu i bierzmowania, czy téz zastrzec dla biskupa obrzęd bierzmowania, przez co wyraża

78 Por. P. Libera, Vistęp do przekładu "De Isaac vel anima". PSP $35 / 2,123$.

79 Por. De Is aac vel anima $5,44-48$ i $8,65-79$, PL 14, 543-545 1 553-560, tłula. P. Libera, PSP 35/2, 148-151 i 162-172. 
s1e więź ochrzczonego z Kościołem lokalnym, ale rozdziela się te dwa sakramenty. Liturgia mediolańska nie znała tych problemóm. Praktyka chrztu udzielanego w wieku dorosłym pozwalała wyrazić oble te wartości. Jedność liturgii nie oznaczała jednak jednolitośc1 obrzędów. Nadal była zachowana jedność $\mathbf{w}$ wielości. Liturgia miała potrójna strukture 1 kolejność etapów.

Centralnym tematem teologicznej refleksji św. Ambrożego jest śmierć $i$ zinartwychwstanie. Jego teksty, mówiące o chrzcie, moźna zgrupować wokół takich wyrażeń, jak: "lavacrum", "lavare" 1 "ablutio", "abluere"80. Po przypomnieniu neoficie jego wejścia do źródła chrzcielnego, stawia on pytanie: "Czym jest chrzest?"81 1 wyjaśnia uwzględniając w swej metodzie nauczania pewne typologie 1 teksty biblijne. Znaczenie zanurzenia wodzie objaśnia Ambroży w kontekścio tematu: powrót człowieka grzesznego poprzez chrzest do stanu stworzenia. Bóg bowiem nie strorzyz człowieka dla śmierci, ale z chwila, gdy człowiek popełnił grzech, sprawił, że śmierć weszła na świat 1 położyła kres grzechowi. Dlatego każda śmierć odbiera możliwość popełnienia grzechu. Śmieré zaś Chrystusa zwyciężyła grzech, a Jego zmartwychwstanie przywróciło człowiek owi utracony dar życia. Ten zbawczy zamysł Boży urzeczywistnia sie w kazdym chrzcie, a mianowicie sprawia, ż człowiek, chociaz żywy, umiera, a żyjąc zmartwychwstaje:

"Co to znaczy: żywy? To mianowicle, że jego clało żye w chwili, gdy podchodzi do sadzawki chrzcielnej 1 niej sie zanurza. A woda, czyż ona nie pochodzi właśnie z ziemi? Spełnia się więc wyrok nieba, ale bez śmiertelnego odrętrienia. Przez to, że zanurzasz się, wykonany zostaje wyrok: 'Jesteś ziemia 1 do ziemi pójdziesz' / Fdz 3, 19/. Z chwilą zaś jego spełnienia się może zaczųć oddziaływać

80 Por. De mysteriis $7,41,5 \mathrm{Sh} 25$ bis, 178; Apologia prophetae David I 12, 59, CSEL 32/2, 340; De sacramentis I 16, SCh 26 bis, 68; De patriarchis 10, 44-45, CSEL 32/2, 149; Expositio Evangelit secundum Lucalis II 83 i IV 5, CCL 14,67 i 107.

81 Por. De sacramentis II 6, 16, SCh 25 bis, 82. 
błogosławione lekarstwo niebieskie. A więc woda pochodzi z ziemi ... woda ma właściwości obmywania. Dlatego sadzawka chrzcielna jest jakby miejscem pogrzebu/Ideo fons quasi sepultura/"82.

W całym tym rozumowaniu opartym na przesłankach biblijnych 1 patrystycznych Teolog z lífiolanu ukazuje paralellzm między śmiercia $i$ zmartwychwstaniem Chrystusa a zanurzeniem neofity wodzie / = śmierć/ 1 jego wyjściem z wody /= zmartwychwstanie/. Temat ten pogłębia w "De sacramentis" 1 wyjaśnia go w świetle gzóstego rozdziału listu sw. Pawła do Rzynian ${ }^{83}$. Na płaszczyźnie duchowo-moralnej następuje upodobnienie neofity do Chrystusa: ukrzyzowanie dla świata, śmierć i pogrzebanie dla grzechu, zmartwychmstanie dla zycia wasce. W takim ujeciu śmierć 1 zmartwychwstanie Chrystusa nabiera szerszego znaczenia, obejmuje zarówno działanie obrzędów sakramentu chrztu, jak 1 dziaJanie o typie ascetyczno-duchowym ${ }^{84}$. Neofita umierając wraz z Chrystusem wrzcie, umarł raz na zawsze, 1 nie powinien ponownie umierać przez powrót do dawnych swoich przyzwyczajeńs ${ }^{85}$. Przez chrzest ludzie umierają dla dawnych swych grzechów 1 uczynkow nieprawych, aby zmartwychwstac zyciu i obyczajach sprawiedliwych. Znaczenie zatem chrztu przekracza sano "oczyszczenie z grzechów", bo stanowi uczestnictwo w śmierci 1 w zmartwychrstaniu Chrystusa, co Ambroźy uznaje za fakt sakramentalny 1 proces duchowo-ascetyczny rozwoju cnót życia chrześcijańskiego. W chrzcie nastepuje prawdziore "wznoszenie sie duszy", to znaczy zgodnie z językiem 1 kultura tamtych czasów - człowieka ku Chry stusowi. Myśl ta jest główna idea wszystkich pouczeń Biskupa Mediolanu przekazywanych neofitom.

Pojęcie "mznoszenta się duszy" precyzuje przez pojęcie doskonalenia 1 świadectwa. Chrześcijanin zjednoczony z Chrystusem stale wzrasta 1 dojrzewa w swoim plelgrzymowaniu oraz zyje juz tylko zyciem Kościoła, polegającym na miłośc1 1 gorliwości apostolsikiej o innych.

Ks. Augustyn Eckmann - Lublin

82 Por. De sacramentis II 6, 19, SCh 25 b1s, 84, POK 26. 64.

83 Por. tanże, II 7,23 , SCh 25 bis, 86.

84 Por. H. Caprioli, Battesimo e confermazione, dz.cyt., 55; E. Dassmann, D1e Frommigkeit des K1rchenvaters Ambrosius von Ma1land, Mtinster 1965.

85 Por. Expositio in Psalmum 118, 18, 22, PL 15, 1460 . 


\section{LITURGY AND THLOLOGY OF ST. AUGUSTINE'S BAPTISM IN MILAN /Summary/}

The liturgy of baptism performed by St. Ambrose consisted of three parts: prebaptismal, baptismal and postbaptismal rites. The prebaptismal rites included the rites of the opening/mysteria apertionis/, prebaptismal unction and renouncement of Satan. The rites of the opening consisted of the catechetic part /traditio symboli, apertio narium, apertio aurium/ and exorcisms. Some of the rites were constituted by the so-called "scrutanina". On the fourth Sunday of Lent catechumen uttered aloud, before their community, the so-called "return of a symbol"/redditio symboli/. The rites of baptism consisted of two basic parts: the consecration of the spring and the wash and submersion of the neophyte. The postbaptismal rites included: the unction after baptisin, washing the feet and clothing in a garment.

The leading subject of St. Ambrose's theological reflections was death and Resurrection. The significance of baptism exceeds pure absolution from sin, as it also constitutes the participation in the death and resurrection of Christ, which St. Ambrose accepts to be a sacramental fact and a spiritually ascetic process of developing the Christian life virtues. He presents the complexity of postbaptismal rites as the development of the Grace of Baptisin, first of all that of the faith and the unity of the Church, which is necessary for a complete union with Christ in Eucharist. On the night $24 / 25$ th of April, 387 , Adeodat and Alipius were baptized by St. Ambrose together with St. Augustine. The latter bishop of IIippo Regius wrote about his baptism: "We were baptized and the anxiety for the past life dispelled"。 